\title{
Temporomandibular Eklem Bozukluklarında Yağ Grefti ve Trombositten Zengin Fibrinin Doku Onarımı Üzerine Kombine Etkisi*
}

\author{
Mehmet KÖSE ${ }^{1 \#}$, Senem Esin YAVAŞ ${ }^{2}$, Semiha ERSOY ${ }^{3}$, Ramazan KAHVECí $^{1}$ \\ 1 Bursa Uludağ Üniversitesi Tıp Fakültesi, Plastik, Rekonstriktif ve Estetik Cerrahi Anabilim Dalı, Bursa. \\ 2 Bursa Uludağ Üniversitesi Sağlık Bilimleri Enstitüsü, Tıp-Histoloji ve Embriyoloji Anabilim Dalı, Bursa. \\ 3 Bursa Uludağ Üniversitesi Tıp Fakültesi, Histoloji ve Embriyoloji Anabilim Dalı, Bursa.
}

\section{ÖZET}

Temporomandibular eklem (TME), memeli çenesinin hareketleri için gerekli olan sinoviyal bir eklemdir, vücutta en sık kullanılan eklemlerden biridir. Yaşlı hastalarda primer olarak görülebilen, bazı patolojik durumlarda (travma ve internal derangement) sekonder olarak gelişen osteoartrit TME'de en sık görülen artrit tipidir. TME patolojilerinin, kıkırdak dokunun histolojik yapısı gereği iyileşme potansiyeli düşük olduğu için, klinik tedavileri sınırlıdır. Bu çalışmada farklı hücrelere dönüşme potansiyeli olan yă̆ doku kaynaklı kök hücrelerin, birçok büyüme faktörü barındıran Trombositten Zengin Fibrin (PRF) ile uyarılarak, hasar olușturulan TME kıkırdağı üzerindeki kombine etkilerinin araştırılması amaçlandı. Çalışmada tavşanların her iki TME eklem disk laterallerinde $3 \mathrm{~mm}$ 'lik defektler oluşturuldu. Sağ tarafa ense-sırt bölgesinden alınan yağ grefti ve tavşanın kendi kanından hazırlanan PRF yerleştirildi, sol tarafi sham grubu olarak planlanıp başka işlem yapılmadan kapatıldı. 8 hafta sonunda eklem kondil ve diskleri çıkarıldı, Hematoksilen\&Eozin (H\&E) ve Safranin O-Fast Green metodları ile boyanarak incelendi. Her iki grup için eklem yüzey yapısı, kondrosit yoğunluğu, hücre kümelenmesi ve Safranin O-Fast Green boyanma kaybı histopatolojik olarak derecelendirildi. Değerlendirilen parametreler arasında anlamlı fark saptanmadığı için, deneysel TME defekt modelinin onarımında yağ grefti ve PRF kombinasyonu etkili bulunmadı.

Anahtar Kelimeler: Temporomandibular Eklem. Yağ Grefti. Trombositten Zengin Fibrin.

Combined Effect of Fat Graft and Platelet-Rich Fibrin on Tissue Recovery in Temporomandibular Joint Defects

\begin{abstract}
Temporomandibular joint (TMJ), is a synovial joint necessary for the movements of mammal chin and one of the most frequently utilized joints of the body. Osteoarthritis that is formed primarily on elder patients or secondarily on some pathological cases (trauma and internal derangement) is the most common type of arthritis of TMJ. Recovery potential of TMJ pathologies is low due to the histological structure of the cartilage tissue and therefore, clinical treatment of these pathologies is limited. In this study, the effects of fat tissue-derived stem cells that have the ability to differantiate into different cells and is stimulated with Platelet-Rich Fibrin (PRF) that contains many growth factors on artificially damaged TMJ is investigated. In this study, $3 \mathrm{~mm}$ defects were created on the lateral sides of both TMJ discs of the rabbits. Fat grafts obtained from the neck-dorsal region and PRF prepared from the rabbits' own blood were placed on the right side and the left side of each rabbit is planned as the sham group and closed without further treatment. After eight weeks, joint condyles and discs were removed, stained with Haematoxylen\&Eosin (H\&E) and Safranin O/Fast Green and histologically examined. Joint surface structures, chondrocyte densities, cell aggregations and losses of Safranin O/Fast Green staining of both of the groups were scored histopathologically. There was no significant difference between investigated parameters and thus, fat graft and PRF combination wasn't concluded to be effective on experimental TMJ defect model recovery.
\end{abstract}

Key Words: Temporomandibular Joint. Fat Graft. Platelet-Rich Fibrin.

Geliş Tarihi: 22.Eylül.2020

Kabul Tarihi:03.Kasım.2020

Dr. Semiha ERSOY

Bursa Uludağ Üniversitesi Tıp Fakültesi,

Histoloji ve Embriyoloji Anabilim Dalı,

Bursa.

Tel: 02242954063

E-posta: semihaersoy@uludag.edu.tr
* X. Ulusal \& Uluslararası Veteriner Patoloji Kongresi'nde (27-31 Ekim 2020, Burdur, Online) Sözlü bildiri olarak sunulmuştur.

\# Güncel Adres: Dr. Mehmet KÖSE Serbest Hekim olarak çalışmaktadır.

Yazarların ORCID ID Bilgisi:

Mehmet KÖSE: 0000-0003-2148-2355

Senem Esin YAVAŞ: 0000-0002-6949-1210

Semiha ERSOY: 0000-0002-6419-0304

Ramazan KAHVECi: 0000-0002-3746-6280 
Temporomandibular eklem (TME), mandibular kondili temporal eklem yüzeyine bağlayan sinoviyal eklemdir. İnsan vücudunda en sık kullanılan eklemlerden biridir. Bu eklemin kondiler kıkırdağı, ekleme yüklenecek mekanik hasardan koruyan yoğun kollajen lifleri ve hücre dışı proteoglikanları içeren avasküler, sıkıștırılabilir bir dokudur. Kollajen lifleri esas olarak tip I ve tip II kollajenden oluşur ve kayma gerilimine direnç sağlayacak şekilde hizalanmıştır ${ }^{1}$. Bu eklemi en sik etkileyen patolojik durumlar; travmalar, inflamatuar ve dejeneratif hastalıklardır. Eklem diskinin yer değiştirmesi (internal derangement), geçirilen cerrahi işlemler, osteoartrit, inflamatuar hastalıklar farklı mekanizmalarla disk ve eklem yüzeylerinde hasara neden olmaktadırlar².

Temporomandibular eklem osteoartriti (TME OA) farklı patolojilere sekonder veya yaşlanma nedeniyle eklem kıkırdağı ve etraf dokuların hasarlanması ile oluşan yaygın dejeneratif bir hastalıktır ${ }^{1}$. Osteroartritte artiküler kıkırdak erozyonları ve fibrilasyonlarının yanı sıra artiküler kondrositlerin kümelenmesi gözlenir ${ }^{3}$. TME OA'nde tipik olarak eklem kıkırdak yüzeylerinde ilk fibrilasyon vardır, ancak sonunda kıkırdak doku tamamen kaybolur. Açı̆̆a çıkan kemik incelir ve sinoviyal sıvı, mikro delikler yoluyla kemik iliğine girebilir. Bu durum, kondiler şeklin kademeli olarak değiştiği kavitasyon ve erozyona neden olabilir ${ }^{4}$.

TME OA patogenezi ve altta yatan moleküler mekanizmalar belirsizliğini korumaktadır. TME OA için güncel tedaviler k1kırdak ve subkondral kemiğin y1kımını önlemeyi, eklem ağrısını hafifletmeyi ve TME işlevini geri kazanmayı amaçlamaktadır. Klinikte fiziksel tedaviler, oklüzal ateller, nonsteroid antiinflamatuvar ilaçlar (NSAID'ler), şiddetli semptomları olan hastalara cerrahi müdahale uygulanmaktadır. Ancak tüm bu tedaviler hastalığın ilerleyişini kısmen durdursa da disk hasarından kaynaklanan fonksiyonel bozulmayı tümüyle geri kazandıramamaktadır ${ }^{1}$.

Hücresel tedavi yöntemlerinin yaygınlaşması ve kolay elde edilebilmeleri, yüksek farklılaşma potansiyelleri nedeniyle kök hücrelerin bir alt populasyonu olan mezenkimal kök hücreler, doku rejenerasyonu alanında araştırılan ve çalışılan hücreler haline gelmiştir. Mezenkimal kök hücreler; iskelet kası, yağ dokusu, plasenta, kemik, süt dişleri gibi çeşitli dokularda tanımlanmıştır ${ }^{1}$. Yağ doku kaynaklı kök hücrelerin, kolay elde edilebilmeleri, kemik iliğindeki mezenkimal kök hücrelere kıyasla daha yüksek oranda bulunmaları ve belirgin olarak daha hızlı çoğalabilmeleri gibi kendilerine özgü avantajları vardır ${ }^{5}$. Yağ dokusunda bulunan kök hücrelerin insülin benzeri büyüme faktörü, hepatosit büyüme faktörü, TGF beta1 büyüme faktörü, vasküler endoteliyal büyüme faktörü salgıladı ̆̆ 1 bilinmektedir. Ancak bu faktörlerin yağ grefti uygulamalarında gözlenen anti-inflamatuar, anti- apoptotik, damarlanmayı artırıcı ve fibrozisi azaltıcı etkilerinin moleküler mekanizması henüz tam olarak açıklığa kavuşturulamamıştır ${ }^{6}$.

Chuoukroun ve arkadaşları tarafından geliştirilen trombositten zengin fibrin (PRF), antikoagülansız cam tüp kullanılarak kanın santrifüjü ile hazırlanan fibrin açısından zengin otolog bir jeldir ${ }^{7}$. Çeşitli büyüme faktörlerini yüksek seviyelerde içeren ikinci nesil bir trombosit konsantresidir. Büyüme faktörlerini kademeli olarak serbest bırakır ve aktivitesini 2 haftadan fazla korur. PRF ayrica hücre proliferasyonu ve farkl1laşması için bir iskele görevi gören fibrin çerçevedir ${ }^{8}$. Bir köpek modelinde, PRF uygulanmış eklem kıkırdak hasarının PRF uygulanmayanlara göre daha iyi rejenerasyon gösterdiği bildirilmiştir ${ }^{9}$. Hasarlı TME kıkırdağ1 onarımında BMP2'nin (Bone Morphogenetic Protein) ${ }^{10}$ ve FGF2 (Fibroblast Growth Factor)'nin ${ }^{11}$ de onarıcı etkisinin olduğunu bildiren çalışmalar bulunmaktadir.

Biz de bu çalıșmamızda yağ grefti içerisindeki kök hücrelerin PRF ile etkileştiklerinde, hasarlı TME k1kırdağı üzerindeki kombine etkilerini araştırmayı hedefledik.

\section{Gereç ve Yöntem}

\section{Deney Hayvanlarl}

Çalışma, Bursa Uludağ Üniversitesi Hayvan Deneyleri Yerel Etik Kurulu'nun 11.07.2018 tarihli, 2018-09/01 no'lu kararı ile uygun bulunmuştur. Çalışmada Bursa Uludağ Üniversitesi Deney Hayvanları Yetiştirme, Uygulama ve Araştırma Merkezi'nden temin edilen ağırlıkları 2500-2750 gr arasında olan 10 adet yetişkin Yeni Zelanda Beyazı 1rkı erkek ve dişi tavşan kullanıldı. Tavşanlara 12 saat aydınlık, 12 saat karanlık sağlanan standart laboratuvar koşullarında, ad libitum standart tavşan yemi ve su sağlanarak bakıldı.

\section{Eklem Dejenerasyon Modeli}

Tüm deneklerde anestezi için 4mg/kg Ketamine (Ketalar, Pfizer) ve $20 \mathrm{mg} / \mathrm{kg}$ Xylazine \%2 (Basilazin, baVET İlaç ve San. Ve Tic. A. Ş.) intramusküler uygulandı. Tavşan lateral kantus posteriorundan dış kulak yoluna çizilen horizontal bir çizgi üzerinden yaklaşık $2 \mathrm{~cm}$ 'lik insizyon yapıldı. Yumuşak doku disseksiyonunun ardından süperior eklem boşluğuna ulaşılarak disk retrakte edildi. 3 mm'lik "punch” biyopsi aletiyle diskin lateralinde bir defekt oluşturularak eklem dejenerasyon modeli oluşturuldu.

\section{Yăg Grefti ve PRF Eldesi}

Mazzetti ve ark.'nın çalışmasındaki gibi ${ }^{12}$, deneklerin ense-sırt bileşke bölgesinde yapılan yaklaşı $2 \mathrm{~cm}$ 'lik insizyonla ulaşılan yağ dokusundan $1 \times 1 \mathrm{~cm}$ 'lik yağ greftleri elde edildi (Şekil 1a). Aurikuler venden cam 
tüpe alınan $10 \mathrm{ml}$ kan ile uygun santrifüj yöntemi kullanılarak ${ }^{7}$ PRF elde edildi.

\section{Çalışma Grupları}

Çalışmada 10 denek kullanıldı. 9 deneğin her iki TME diskinde ve kondil eklem yüzeyinde hasar oluşturuldu. 1 denek sağlam yapıyı incelemek üzere seçildi (kontrol grubu). Sağ eklem boşluğuna sırttan elde edilen yağ grefti, PRF ile karıştırılarak uygulandı (deney grubu) (Şekil 1b). Sol ekleme başka işlem uygulanmadı (sham grubu). Kesiler 4.0 prolen sütür ile dikildi. 8 haftalık bekleme sürecinin ardından 10 denek dekapitasyon yöntemi ile sakrifiye edildi. 1 deneğin ekleminde enfeksiyon oluştuğundan, doku elde edilemedi.

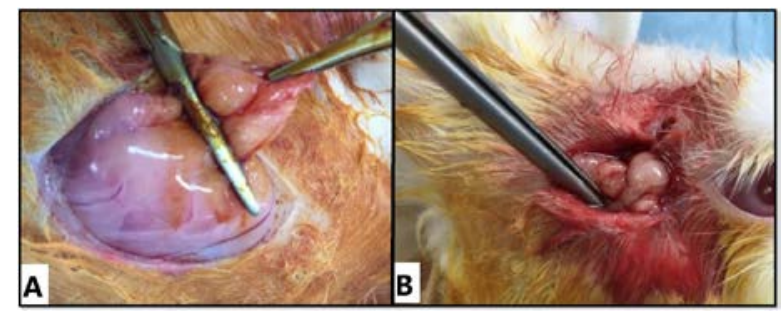

Şekil 1.

Deneklerden yağ dokusu greftinin elde edilmesi (A), Să̆ eklem boşluğuna yă̆ grefti ve PRF karışımının uygulanmasi (B).

\section{Histopatolojik Inceleme}

9 denekten elde edilen toplam 18 kondil, 1şık mikroskobunda incelenmek üzere \%10’luk formalin ile fikse edildi. Ardından dekalsifikasyon işlemi için nötral EDTA solüsyonu uygulandı. Dokulardan kalsiyum uzaklaştırıldıktan sonra doku takibi işlemine geçildi.

8 denekten çıkarılan sağ (deney grubu) ve sol (sham grubu) kondil-disk dokularına ait parafin bloklardan 5 $\mu \mathrm{m}$ kalınlığında alınan seri kesitler, 1 gece boyunca $60^{\circ} \mathrm{C}^{\prime}$ lik etüvde bekletildi ve ksilen ile deparafinize edildikten sonra boyamalar uyguland. HematoksilenEozin boyamalarında kondilin histolojik yapısı, kondrosit yoğunluğu ve kondrosit kümelenmeleri incelendi. Safranin O-Fast Green boyamalarında ise ilave olarak özellikle k1kırdak doku matriks komponentlerinden olan kollajen lifler ve matriks proteoglikanları değerlendirildi. Hiçbir işlem yapılmayan 1 denekten alınan dokular ise, sağlam kondil-disk dokularını görmek ve diğer gruplar ile karşılaştırma yapmak amacıyla kontrol olarak kullanıldı.

Kriterlere ve değerlendirmelere ait preparatlardan Olympus BX50 fotomikroskop ile görüntüler elde edildi.

\section{Histopatolojik Skorlama}

Çalışmamızdaki osteoartritik değişiklikleri doğrulamak için, bir histolojik skorlama sistemi (OARSI) seçildi $^{13}$ (Tablo I). Genel yapı, kondrosit yoğunluğu, hücresel kümelenme, Safranin O-Fast Green boyanma kaybı parametreleri iki araştırmacı tarafından kör bir şekilde puanland1.

\section{Tablo I. OARSI skorlamas1}

\begin{tabular}{|c|}
\hline Parametreler \\
\hline $\begin{array}{l}\text { Yapı skorlaması } \\
0=\text { normal } \\
1 \text { = yüzey düzensizlikleri } \\
2 \text { = yüzeyin \% 50'sinden azında, yarıklar } \\
3 \text { = yüzeyin \% 50'si ve fazlasında, yarıklar } \\
4 \text { = yüzeyin \% 50'sinden azında, hiyalin kıkırdağın } 1 / 3 \text { 'ünde aşınma } \\
5 \text { = yüzeyin \% 50'si ve fazlasında, hiyalin kıkırdağın } 1 / 3 \text { 'ünde aşınma } \\
6 \text { = yüzeyin \% 50'sinden azında, hiyalin kıkırdağın 2/3'ünde aşınma } \\
7 \text { = yüzeyin \% 50'si ve fazlasında, hiyalin kıkırdağın } 2 / 3 \text { 'ünde aşınma } \\
8 \text { = yüzeyin \% 50'sinden azında, hiyalin kıkırdakta tam derin aşınma } \\
9=\text { yüzeyin \% 50'si ve fazlasında, hiyalin kıkırdakta tam derin aşınma } \\
10 \text { = yüzeyin \%50'sinden azında, subkondral kemiğin kalsifiye kıkırdağın- } \\
\text { da ve hiyalin kıkırdakta tam derin aşınma } \\
11 \text { = yüzeyin \%50'si ve fazlasında, subkondral kemiğin kalsifiye kıkırda- } \\
\text { ğında ve hiyalin kıkırdakta tam derin aşınma }\end{array}$ \\
\hline $\begin{array}{l}\text { Kondrosit yoğunluğu skorlaması } \\
0=\text { hücrelerde azalma yok } \\
1 \text { = hücrelerde fokal azalma } \\
2 \text { = hücrelerde multifokal azalma } \\
3 \text { = hücrelerde konfluent multifokal azalma } \\
4 \text { = Hücrelerde diffüz azalma }\end{array}$ \\
\hline $\begin{array}{l}\text { Kondrositlerde kümelenme skorlaması } \\
0=\text { normal } \\
1=\text { kümelenme }<4 \\
2=4 \leq \text { kümelenme }<8 \\
3=8 \leq \text { kümelenme }\end{array}$ \\
\hline $\begin{array}{l}\text { Safranin } 0 \text { - Fast Green boyanma kaybı } \\
0=\text { eklem kıkırdağı boyunca üniform boyanma } \\
1=\text { kondil boyunun \% } 50 \text { 'sinden azında, hiyalin kıkırdak yüzeyinde } \\
\text { boyanma kaybı } \\
2=\text { kondil boyunun } \% 50 \text { 'si ve fazlasında, hiyalin kıkırdak yüzeyinde } \\
\text { boyanma kaybı } \\
3=\text { kondil boyunun } \% 50 \text { 'sinden azında, hiyalin kıkırdağın üst } 2 / 3 \text { 'ünde } \\
\text { boyanma kaybı } \\
4=\text { kondil boyunun } \% 50 \text { 'si ve fazlasında, hiyalin kıkırdağın üst } 2 / 3 \text { 'ünde } \\
\text { boyanma kaybı } \\
5=\text { kondil boyunun } \% 50 \text { 'sinden azında, tüm hiyalin kıkırdakta boyanma } \\
\text { kaybı } \\
6=\text { kondil boyunun } \% 50 \text { 'si ve fazlasında, tüm hiyalin kıkırdakta boyanma } \\
\text { kaybı }\end{array}$ \\
\hline
\end{tabular}

\section{İstatistiksel Analiz}

Verilerin normal dağılıma uygunluğu Shaphiro-Wilk testi ile test edilmiş, normal dağılıma sahip özelliklerin 2 bağımsız grupta karşılaştırılmasında Independent Sample Test, normal dağılmayan özelliklerin 2 bağımSız grupta karşılaştırılmasında Mann Whitney U testi kullanılmıştır. Tanımlayıcı istatistik olarak sayısal değişkenler için ortalama \pm standart sapma, İstatistiksel analizler için SPSS Windows version 22.0 paket programı kullanılmış ve $\mathrm{P}<0.05$ istatistiksel olarak anlamlı kabul edilmiştir. 


\section{Bulgular}

Hematoksilen-Eozin ve Safranin O-Fast Green ile boyanmış kontrol deneğine ait sağlam kondil histolojisi ve boyanma özellikleri Şekil $2 \mathrm{a}$ ve b'de görülmektedir. Deney ve sham gruplarına ait boyanmış kondil kesitlerinde ise; çeşitli derecelerde olmak üzere (Tablo II) yüzey düzensizlikleri ve fissürler, kondrosit kümelerinin oluşumu, hücrelerde fokal azalma, boyanmada azalma gibi osteoartritin klasik histopatolojik özellikleri Şekil 2c ve d'de izlenmektedir. Deney ve sham gruplarına ait skorlamaların istatistiksel değerlendirme sonuçları Tablo III’te verilmiştir.

Tablo II. Histopatolojik skorlama değerleri

\begin{tabular}{|c|c|c|c|c|c|}
\hline \multicolumn{2}{|c|}{$\begin{array}{c}\text { Kondil } \\
\text { Değerlendirmesi }\end{array}$} & Yapı & $\begin{array}{c}\text { Kondrosit } \\
\text { yoğunluğu }\end{array}$ & $\begin{array}{c}\text { Küme- } \\
\text { lenme }\end{array}$ & $\begin{array}{c}\text { Boyanma } \\
\text { kaybı }\end{array}$ \\
\hline Kontrol & Sol/Sağ & $0 / 0$ & $0 / 0$ & $0 / 0$ & $0 / 0$ \\
\hline $\mathbf{1}$ & Sol/Sağ & $6 / 4$ & $1 / 2$ & $1 / 2$ & $4 / 4$ \\
\hline $\mathbf{2}$ & Sol/Sağ & $7 / 9$ & $2 / 4$ & $3 / 0$ & $4 / 5$ \\
\hline $\mathbf{3}$ & Sol/Sağ & $9 / 10$ & $4 / 4$ & $2 / 2$ & $6 / 6$ \\
\hline $\mathbf{4}$ & Sol/Sağ & $7 / 4$ & $3 / 1$ & $1 / 3$ & $5 / 3$ \\
\hline $\mathbf{5}$ & Sol/Sağ & $7 / 6$ & $2 / 2$ & $3 / 3$ & $4 / 3$ \\
\hline $\mathbf{6}$ & Sol/Sağ & $5 / 11$ & $1 / 4$ & $1 / 3$ & $4 / 6$ \\
\hline $\mathbf{7}$ & Sol/Sağ & $11 / 11$ & $4 / 4$ & $3 / 3$ & $6 / 6$ \\
\hline $\mathbf{8}$ & Sol/Sağ & $1 / 6$ & $1 / 3$ & $0 / 1$ & $3 / 3$ \\
\hline
\end{tabular}

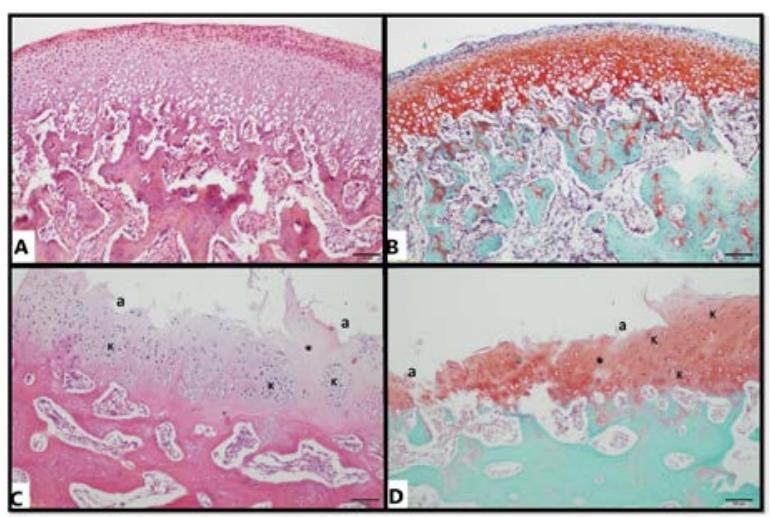

Şekil 2.

Sağlam kondil histolojisi (A-B), TME osteroartrit histopatolojisi (C-D); yüzey düzensizlikleri, fissürler ve aşınma (a), kondrosit kümeleri $(K)$, hücrelerde fokal azalma (*). H\&E (A,C), Safranin O-Fast Green $(B, D)$.

0 ile 11 arasında skorlanan kondillerdeki yapısal değişiklikler; yüzeyel aşınmadan tam derin erozyona kadar değişen derecelerde izlendi (Şekil 3a-h). Ancak deney ve sham grupları arasında istatistiksel olarak anlaml düzeyde bir farklılık saptanmadı ( $\mathrm{p}>0.05)$ (Tablo III) (Şekil 7a).

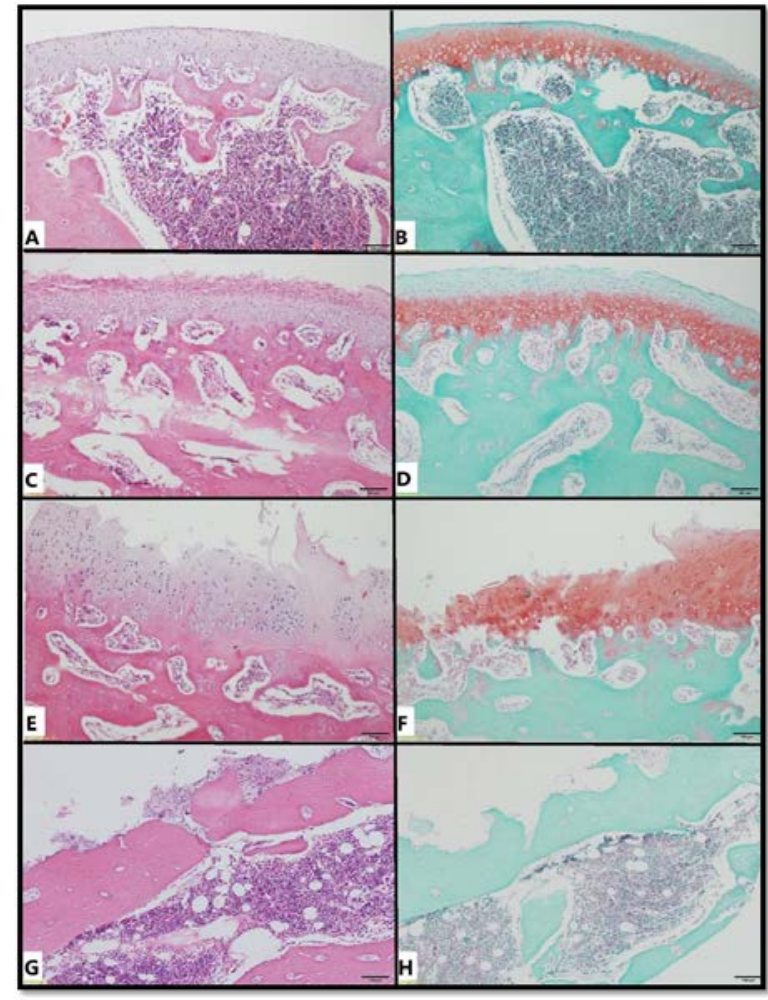

Şekil 3.

Yapısal değişiklik; Skor 1 (A-B), Skor 4 (C-D), Skor 7 ( E-F), Skor $11(G-H)$. H\&E (A,C,E,G), Safranin OFast Green $(B, D, F, H)$.

Tablo III. Histopatolojik skorlamaların ortalama, medyan ve $P$ değerleri

\begin{tabular}{|c|c|c|c|c|c|}
\hline & \multicolumn{2}{|c|}{ Deney $(n=8)$} & \multicolumn{2}{|c|}{ Sham $(n=8)$} & \\
\hline & Ort士SS. & Medyan & Ort土SS. & Medyan & $\mathbf{P}$ \\
\hline $\begin{array}{c}\text { YAPI } \\
\text { *Independent } \\
\text { Sample Test }\end{array}$ & $6,62 \pm 2,92$ & 7 & $7,62 \pm 2,97$ & 7,5 & $0,509^{*}$ \\
\hline $\begin{array}{c}\text { KONDROSIT } \\
\text { YOĞUNLUĞUNDA } \\
\text { AZALMA } \\
\text { *Mann Whitney } \\
\text { U Test }\end{array}$ & $2,28 \pm 1,28$ & 2 & $3 \pm 1,19$ & 3,5 & $0,228 *$ \\
\hline $\begin{array}{c}\text { KONDROSIT } \\
\text { KÜMELENMESi } \\
\text { *Mann Whitney U } \\
\text { Test }\end{array}$ & $1,75 \pm 1,77$ & 1,5 & $2 \pm 1,19$ & 2,5 & $0,655^{*}$ \\
\hline $\begin{array}{c}\text { BOYANMA KAYBI } \\
\text { *Mann Whitney U } \\
\text { Test }\end{array}$ & $7,62 \pm 1,05$ & 7,5 & $6,62 \pm 1,03$ & 7 & $0,913^{*}$ \\
\hline
\end{tabular}

Kondrosit yoğunluğu/kaybı, 0 ile 4 arasında skorland1rıldı. Kondrosit kaybının olduğu alanlar, asellüler bölgeler olarak izlendi (Şekil 4a-h). Gruplar (deney ile sham) arasında bu kriter için hesaplanan fark ( $p>0.05)$ (Tablo III), istatistiksel olarak anlamlı bulunmadı (Şekil 7b). 


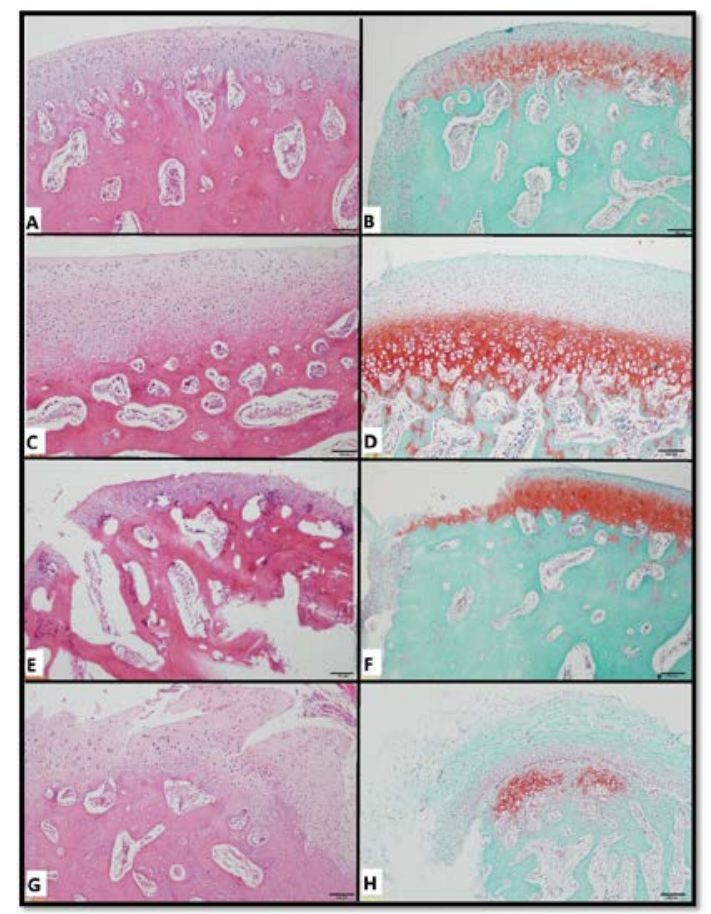

Şekil 4.

Kondrosit yoğunluğunda azalma; Skor 1 (A-B), Skor 2 (C-D), Skor 3 ( E-F), Skor $4(G-H)$. H\&E (A,C,E,G), Safranin O-Fast Green $(B, D, F, H)$.

0 ile 3 arasında skorlandırılan kondrosit hücre kümelenmesi Şekil 5a-h’de izlenmektedir. Bu parametre yönünden deney ve sham grupları arasında belirlenen fark ( $p>0.05$ ), istatistiksel olarak anlamlı değildi (Tablo III) (Şekil 7c).

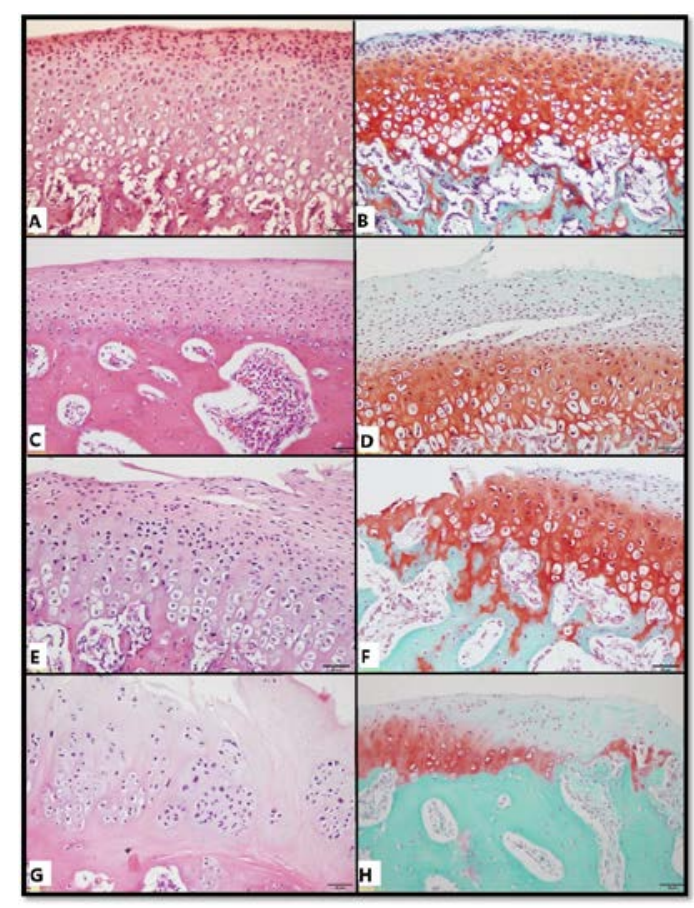

Şekil 5 .

Kümelenme; Skor 0 (A-B), Skor 1 (C-D), Skor 2 (E-F), Skor $3(G-H)$. H\&E (A,C,E,G), Safranin O-Fast Green $(B, D, F, H)$.
Yapısal/hücresel değişikliklere ek olarak, kıkırdak doku matriks komponentlerinden olan kollajen lifler ve matriks proteoglikanları Safranin O-Fast Green boyaması ile değerlendirildi. Kontrol deneğine ait sağlam kondil örneğinde Safranin $\mathrm{O}$ boyamasının homojen olarak dağıldığı gözlendi (Şekil 1b). 0 ile 6 arasında skorlanan deney ve sham gruplarında ise kondilin üst 1/3-2/3'ünde değişen bir boyanma kayb1 belirlendi (Şekil 6a-d). Her iki grup arasında Safranin O-Fast Green boyamaları ile kıkırdak dokusundaki boyanma kaybında izlenen fark, istatistiksel olarak anlamlı bulunmadı ( $\mathrm{p}>0.05)$ (Tablo III) (Şekil 7d).

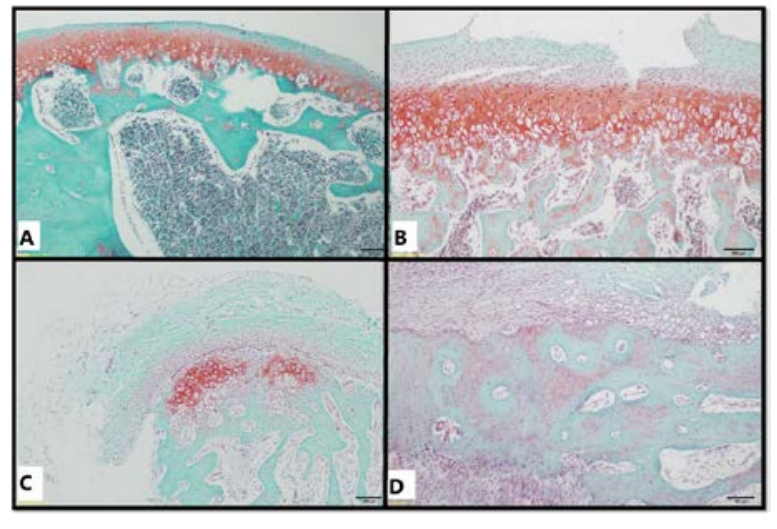

Şekil 6.

Boyanma kaybı; Skor 3 (A), Skor 4 (B), Skor 5 (C), Skor 6 (D). Safranin O-Fast Green.

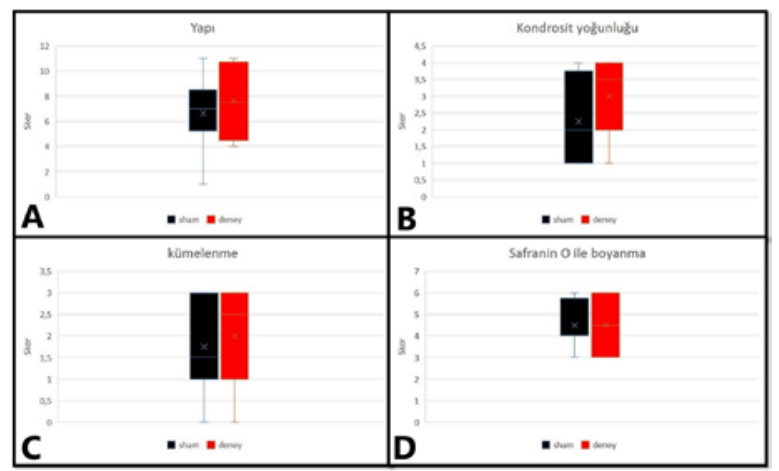

Şekil 7

Deney ve sham gruplarının skor değerlendirmesi ve ortalama değerleri grafiği. Yapısal değişiklikler (A), kondrosit yoğunluğunda azalma (B), kümelenme (C), boyanma kaybı (D).

Bazı deneklerde kondiler kıkırdaktaki şiddetli osteoartritik yapısal değişiklikler; subkondral kemiğe kadar derin erozyon ve yaygın hücre kaybı şeklinde (Skor 11) gözlenmiştir (Şekil 3g,h). Kıkırdak erozyonu sebebiyle proteoglikan içeriğinin kaybı, Safranin O boyanmasına tam silinme olarak yansımıştır (Şekil 3h).

\section{Tartışma ve Sonuç}

OA gelişimi hakkında yaygın olarak kabul edilen teori, uygulanan kuvvetlerin eklem yüzeyinin potansiyelini 
aşması sonucu bozulmaya yol açmasıdır. Mandibulanın postero-superior yer değiştirmesi kalıcı aşırı yüklenmeyle, TME'in yük potansiyelini aşabilir ve disk deformitesinde progresif bir artışa yol açabilir ${ }^{4}$. Disk patolojilerinin osteoartritin nedeni mi yoksa sonucu mu olduğu ise net değildir, etiyolojik faktörlerin ikisine birden neden olduğu düşünülmektedir ${ }^{14}$. Bir çalışmada, disk patolojilerinden kaynaklanan TME osteoartritinin hayvan modeli tasarlanmış, patolojik diskin eklem yumuşak dokusunda heterotrofik kemikleşmeye ve kondilde deformiteye neden olduğu gösterilmiștir²

Çalıșmamızda da, disk patolojilerinden kaynaklanan eklem dejenerasyon modeli uygulandı. Histopatolojik olarak değerlendirilen kondillerde yüzey yapısında bozulmalar, kondrosit kümelenmesi, kondrosit yoğunluğu ve Safranin O-Fast Green ile boyanma kaybı olarak izlenen değişikliklere bağlı olarak, dejenerasyon modelinin başarılı bir şekilde oluşturulduğu düşünüldü.

Kalay ve ark.'nın çalışmasında ${ }^{15}$, yağ grefti uygulanan eklemlerde makroskopik olarak daha iyi iyileşme belirtileri gözlense de, mikroskobik bulgularla yapılan değerlendirmede bu veriler anlamlılığa ulaşmamıştır. Bir başka araştırmada ise; insan yağ dokusu kaynaklı kök hücrelerin ekstrasellüler vezikülleri (hASCEV)'nin kıkırdağı dejenerasyondan etkili bir şekilde koruduğu ve OA progresyonunu zayıflattığı gösterilmiştir $^{16}$.

Kütük ve ark. ${ }^{17}$ nın yaptığı çalışmada; PRP’nin eklem yüzeyleri üzerine etkisi araştırılmış, istatistiksel olarak anlamlı bir sonuca ulaşılmasa da, mikroskobik görüntülerde PRP'nin kıkırdak iyileşmesi üzerine pozitif etkisinin görüldüğü bildirilmiştir. Klasik PRP üretiminde kanın pıhtılaşmasını engellemek için kullanılan ajanlar yara iyileşmesini olumsuz etkilediğinden, çalışmamızda ikinci nesil trombosit konsantresi PRF tercih edilmiştir. Ayrıca PRF, PRP'ye göre daha yüksek miktarlarda TGF-1 salgılar, büyüme faktörlerini daha uzun süre serbest bırakır ve daha güçlü bir hücre göçü indüksiyonuna sahiptir ${ }^{18}$. Bir köpek modelinde, PRF uygulanan eklem kıkırdak kusurlarının, PRF'siz olanlara göre daha iyi rejenerasyon gösterdiği bildirilmiştir'.

Tavşanlar genellikle kıkırdak rejenerasyonunu değerlendirme çalışmalarında kullanılmakla birlikte, 3 mm'lik defektlerin kendiliğinden iyileşme gösterdiği bildirilmiştir $^{19}$. Çalışmamızda olumlu rejeneratif etki saptanmaması; bildirilen bu spontan iyileşme nedeniyle olabileceği gibi, TME'in tavşanlarda beslenme amaçlı gün boyu aktif olması ve hareket nedeniyle çevreden yeterli vaskülarizasyonun sağlanamaması nedeniyle de olabilir.

Maruyama ve ark. ${ }^{8}$, tavşan tibiasında oluşturulan defektte PRF ve PRP'nin rejenerasyona etkisini karşılaştırmış ve PRF'yi anlamlı olarak etkili bulmuşlardır ve benzeri hareketsiz yapılardaki çalışma sonuçlarının daha iyi olduğunu ifade etmişlerdir. Ayrıca kemik iliği kaynaklı kök hücrelere kıyasla, yağ dokusu kaynaklı kök hücrelerin PRP uyarımına karşı daha düşük bir tepkiye sahip oldukları, in vitro ve in vivo kondrojenik farklılaşmada etkilerinin daha sınırlı olduğu bildirilmiştir $^{20}$. Bu iki çalışma bulguları da çalışmamızın sonuçlarını destekler niteliktedir.

Barındırdığ niyle, benzer kıkırdak dokulardan alınan otogreftler TME diskinin yerini tutamamaktadır. Yaşam için son derece önemli ve bir o kadar da aktif kullanımı olan TME'in dejenerasyonlarında onarımın sağlanabilmesi hem klinik uygulamada hastaların iyileştirilmesinde, hem de rejeneratif tıp alanında yeni uygulamaların hayata geçirilmesi açısından son derece önem taş1maktadır. Sonuç olarak; TME hasarlarında kök hücrelerden zengin yağ dokusu greftlerinin PRF gibi kök hücreleri aktive ettiği düşünülen kombinasyonlar ile, hasarlı eklem ve bunlara ev sahipliği yapan bölge arasında hareketsizliğin ve dolaylı olarak vaskülarizasyonun da korunduğu çalışmalar ile iyileşmenin daha iyi sağlanabileceği düşünüldü.

\section{Etik Kurul Onay Bilgisi:}

Onaylayan Kurul: Uludağ Üniversitesi Hayvan Deneyleri

Yerel Etik Kurulu.

Onay Tarihi: 11.07 .2018

Karar No: 2018 - 09/01

\section{Teşekkür}

Histolojik kesitlerin preparasyonuna katkıları için Biyolog Ayşe AKBAŞ'a teşekkür ederiz.

\section{Kaynaklar}

1. Cui D, Li H, Xu X, et al. Mesenchymal stem cells for cartilage regeneration of TMJ Osteoarthritis. Stem Cells Int 2017;Article ID 5979741, 11.

2. Embree MC, Iwaoka GM, Kong D, et al. Soft tissue ossification and condylar cartilage degeneration following TMJ disc perforation in a rabbit pilot study. Osteoarthritis Cartilage 2015;23:629-39.

3. Huang H, Shank G ,Ma L, Tallents RH, Kyrkanides S. Nerve growth factor induced after temporomandibularjoint inflammation decelerates chondrocyte differentiation. Oral Dis 2013;19:604-10.

4. Imai H, Sakamoto I, Yoda T, Yamashita Y. A model for internal derangement and osteoarthritis of the temporomandibular joint with experimental traction of the mandibular ramus in rabbit. Oral Dis 2001;7:185-91.

5. Zuk PA, Zhu M, Mizuno $\mathrm{H}$, et al. Multilineage cells from human adipose tissue: implications for cell based therapies. Tissue Eng 2001;7:211-28.

6. Gimble JM, Katz AJ, Bunnel BA. Adipose derived stem cells for regenerative medicine. Circ Res 2007;100:1249-60.

7. Choukroun J, Adda F, Schoeffler C, Vervelle A. The opportunity in perio-implantology: the PRF [in French]. Implantodontie 2001; 42:55-62.

8. Maruyama M, Satake H, Suzuki T, et al. Comparison of the effects of osteochondral autograft transplantation with platelet rich-plasma or platelet-rich fibrin on osteochondral defects in a rabbit model. Am J Sports Med 2017; 45:3280-8. 


\section{TME Bozukluklarında Yağ Grefti ve PRF}

9. Kazemi D, Fakhrjou A, Dizaji VM, Alishahi MK. Effect of autologous platelet rich fibrin on the healing of experimental articular cartilage defects of the knee in an animal model. Biomed Res Int 2014;2014:486436.

10. Suzuki T, Bessho K, Fujimura K, et al. Regeneration of defects in the articular cartilage in rabbit temporomandibular joints by bone morphogenetic protein-2. Br J Oral Maxillofac Surg 2002;40:201-6.

11. Takafuji H, Suzuki T, Okubo Y, Fujimura K, Bessho K. Regeneration of articular cartilage defects in the temporomandibular joint of rabbits by fibroblast growth factor-2: a pilot study. Int J Oral and Maxillofacial Surg 2007;36:934-7.

12. Mazzetti MPV, Oliveira IS, Miranda-Ferreira R, et al. Qualitative and quantitative analysis of rabbit's fat mesenchymal stem cells. Acta Cir Bras 2010;25(1):24-7.

13. Laverty S, Girard CA, Williams JM, Hunziker EB, Pritzker KPH. The OARSI histopathology initiative-recommendations for histological assessments of osteoarthritis in the rabbit. Osteoarthritis Cartilage 2010;18:53-65.

14. Murphy MK, MacBarb RF, Wong ME, Athanasiou KA. Temporomandibular joint disorders: A review of etiology, clinical management, and tissue engineering strategies. Int J Oral Maxilofac Implants 2013;28(6):393-414.
15. Kalay A, Kahveci R, Kahveci Z, Halk KZ. Temporomandibular Eklem Disk Bozukluklarında Yağ Greftinin Etkisi. Uludağ Üniversitesi Tıp Fakültesi Dergisi 2018;44(3):159-66.

16. Woo CH, Kim HK, Jung GY, et al. Small extracellular vesicles from human adipose-derived stem cells attenuate cartilage degeneration. J Extracell Vesicles 2020;9(1): 1735249.

17. Kütük N, Baş B, Soylu E, et al. Effect of platelet-rich plasma on fibrocartilage, cartilage, and bone repair in temporomandibular joint. J Oral Maxillofac Surg 2014;72:277-84.

18. Schär MO, Diaz-Romero J, Kohl S, Zumstein MA, Nesic D. Platelet-rich concentrates differentially release growth factors and induce cell migration in vitro. Clin Orthop Relat Res 2015;473(5):1635-43

19. Lietman SA, Miyamoto S, Brown PR, Inoue N, Reddi AH. The temporal sequence of spontaneous repair of osteochondral defects in the knees of rabbits is dependent on the geometry of the defect. J Bone Joint Surg Br 2002;84(4):600-6.

20. Xie $\mathrm{X}$, Wang $\mathrm{Y}$, Zhao $\mathrm{C}$, et al. Comparative evaluation of MSCs from bone marrow and adipose tissue seeded in PRPderived scaffold for cartilage regeneration. Biomaterials 2012;33:7008-18. 
